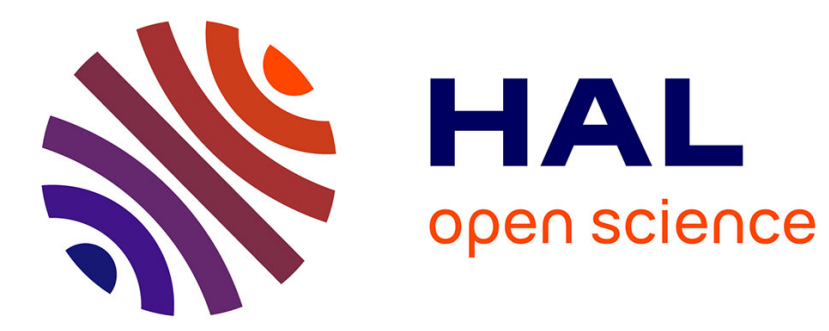

\title{
Simultaneous hydrogen sulfide removal and wastewater purification in a novel alum sludge-based odor-gas aerated biofilter
}

Baiming Ren, Nathalie Lyczko, Yaqian Zhao, Ange Nzihou

\section{- To cite this version:}

Baiming Ren, Nathalie Lyczko, Yaqian Zhao, Ange Nzihou. Simultaneous hydrogen sulfide removal and wastewater purification in a novel alum sludge-based odor-gas aerated biofilter. Chemical Engineering Journal, 2021, 419, pp.129558. 10.1016/j.cej.2021.129558 hal-03205692

\section{HAL Id: hal-03205692 \\ https://imt-mines-albi.hal.science/hal-03205692}

Submitted on 30 Apr 2021

HAL is a multi-disciplinary open access archive for the deposit and dissemination of scientific research documents, whether they are published or not. The documents may come from teaching and research institutions in France or abroad, or from public or private research centers.
L'archive ouverte pluridisciplinaire HAL, est destinée au dépôt et à la diffusion de documents scientifiques de niveau recherche, publiés ou non, émanant des établissements d'enseignement et de recherche français ou étrangers, des laboratoires publics ou privés. 


\title{
Simultaneous hydrogen sulfide removal and wastewater purification in a novel alum sludge-based odor-gas aerated biofilter
}

\author{
Baiming Ren ${ }^{\mathrm{a}, \mathrm{b}, \mathrm{c}}$, Nathalie Lyczko ${ }^{\mathrm{c}}$, Yaqian Zhao ${ }^{\mathrm{d}, *}$, Ange Nzihou ${ }^{\mathrm{c}}$ \\ ${ }^{a}$ Key Laboratory of Subsurface Hydrology and Ecological Effects in Arid Region, Ministry of Education, Chang'an University, Xi'an 710054, PR China \\ ${ }^{\mathrm{b}}$ School of Water and Environment, Chang'an University, Xi'an 710054, PR China \\ ${ }^{\mathrm{c}}$ Université de Toulouse, Mines Albi, CNRS, UMR 5302, Centre RAPSODEE, Campus Jarlard, Albi 81013 Cedex 09, France \\ ${ }^{\mathrm{d}}$ State Key Laboratory of Eco-Hydraulics in Northwest Arid Region, Xi'an University of Technology, Xi'an 710048, PR China
}

Keywords:

Intensified biofilter

Intermittent aeration

Odor control

Sorption

Waterworks residues

WWTPs upgrading

\begin{abstract}
A B S T R A C T
A novel alum sludge-based odor-gas aerated vertical flow biofilter (Al-OAF) was developed, which aims to removal the pollutants in wastewater and simultaneously to eliminate $\mathrm{H}_{2} \mathrm{~S}$ generated from wastewater treatment facility. Three lab-scale parallel columns were operated in batch model while intermittently aerated with 200 ppm $\mathrm{H}_{2} \mathrm{~S}$ (Al-OAF), air (Al-AF) and unaerated (Al-F, as blank), respectively. The pollutants in wastewater and the effluent $\mathrm{H}_{2} \mathrm{~S}$ concentration from Al-OAF were monitored regularly. Results showed that three columns presented a high removal efficiency ( $>98 \%$ ) of total phosphorus (TP) and a completed removal of $\mathrm{H}_{2} \mathrm{~S}(100 \%)$ in Al-OAF. $\mathrm{Al}-\mathrm{OAF}$ and Al-AF could enhance the removal efficiency of chemical oxygen demand (COD) of 94.3 $\pm 3.0,94.8 \pm$ $1.9 \%$, and total nitrogen (TN) of $86.2 \pm 14.2,91.6 \pm 5.4 \%$, respectively. In particular, there was no significant difference regarding the COD, TN removal performances between the " $\mathrm{H}_{2} \mathrm{~S}$ driven" $\mathrm{Al}-\mathrm{OAF}$ and the "air driven" Al-AF. The $\mathrm{H}_{2} \mathrm{~S}$ removal mechanism lies in the alum sludge ability of $\mathrm{H}_{2} \mathrm{~S}$ adsorption and the reaction by the biofilm in the biofilter. This demonstrates that the novel Al-OAF (aerated with waste gas) would be a promising "wise choice" for intensified biofilter with dual-goals of simultaneous wastewater purification and $\mathrm{H}_{2} \mathrm{~S}$ elimination.
\end{abstract}

\section{Introduction}

Traditionally, the mission of wastewater treatment is to remove various pollutants (i.e. organic and nutrients) from wastewater and reduce the environmental impact on receiving waters. However, wastewater treatment processes also release unpleasant odors even virus (i.e. SARS-CoV-2) via aerosol [12] and pose a threat to public health [24]. Generally, odors emanating from wastewater treatment processes are composed of a mixture of various chemical compounds, including nitrogenous compounds (e.g., ammonia $\left(\mathrm{NH}_{3}\right)$ ), inorganic sulfur compounds (e.g., hydrogen sulfide $\left(\mathrm{H}_{2} \mathrm{~S}\right)$ ), volatile organic compounds (e.g., butanone) etc. [7]. Seventy-eight kinds of main odor-producing compounds have been reported [28]. In particular, majority of the odor emissions from sewerage facilities contain $\mathrm{H}_{2} \mathrm{~S}$, and $\mathrm{H}_{2} \mathrm{~S}$ could also cause the corrosion of wastewater networks, environmental pollution and human diseases [21].

Due to the complex nature of odorants released from various treatment process in wastewater treatment plants (WWTPs), the efficient and low-cost odor removal strategy seems a "bottleneck issue" worldwide. Literature has highlighted physical/chemical and biological methods being used for odor abatement $[2,14]$. However, the physical/chemical odor control methods, such as adsorption approach and chemical scrubbing, normally have techno-economical demerits of high operation and management (O\&M) costs to regularly change the sorbents and generate hazardous byproducts etc. $[16,31]$. It seems the "end-of-thepipes" technologies are relatively impractical for odor control both in environmental and "circular economy" terms. Recent reviews [1,2,24] have revealed that the investigation on odor removal has centered on developing the environmentally-friendly benign approaches that can remove odor via simple, efficient, and effective processes. For example, biofiltration (BF) is the most favorite applied biological methods for odor abatement, which had been intensively studied over the last several decades [2]. In BF, the humified odorants are forced through a packed bed where microbes and water are attached as a biofilm. Odorants are biodegraded by the microorganisms and sorbed by filter material [21]. BF aims at maximize odor removal efficiency by utilizing various

\footnotetext{
* Corresponding author.

E-mail address: yaqian.zhao@ucd.ie (Y. Zhao).
} 
microbes and optimized design parameters such as moisture and $\mathrm{pH}$ of the media. However, there is one concern that BF presents large land requirements and likely further improvements to reduce its physical footprint [1].

As a biofilter-like facility, constructed wetlands (CWs) have been widely used as an efficient, cost-effective and sustainable wastewater treatment technology [22]. In particular, vertical flow constructed wetlands (VFCWs) have been developed due to their low footprint and high efficiency for pollutant removal $[6,10]$. VFCWs only require 1-3 $\mathrm{m}^{2} / \mathrm{PE}$ area [17]. Unfortunately, nitrogen $(\mathrm{N})$ removal efficiency remains around $50 \%$ in most operated VFCWs under a nitrogen loading rate of $0.6-2.0 \mathrm{~g} \mathrm{~m}^{-2} \mathrm{~d}^{-1}$ [9], which is still far from satisfactory and fails to meet increasingly stringent $\mathrm{N}$ discharge standards [17]. Thus, improving the internal aerobic concentration is vital for enhancing the nitrification process and increasing the efficiency of biological $\mathrm{N}$ removal to improve the overall removal efficiency in VFCWs. Recent research has focused on enhanced $\mathrm{N}$ removal performance via intensified strategies [8], such as effluent recirculation, artificial aeration, tidal flow and flow direction reciprocation $[10,35]$. In particular, artificial aeration has proven to be a good solution for creating aerobic conditions favorable for nitrification. Earlier, continuous artificial aeration strategies were employed in most studies [19]. However, it inhibits denitrification process due to the lacking of anoxic zone which could decrease the removal of total nitrogen (TN). Thereafter, intermittent aeration was developed by creating alternating aerobic and anaerobic conditions. It benefits both nitrification and denitrification processes and enhances the $\mathrm{N}$ removal efficiency $[27,42]$. However, the high operation costs of the aeration strategy remains questionable $[35,10]$.

Alum sludge is waterworks residue. It is an easily, largely available by-product produced in drinking water treatment plant when aluminum sulfate was used as coagulant for raw water purification. It has been intensively discussed as a recycle product for various environmental applications in line with "circular economy" [23]. Especially for the great adsorption capacity of phosphorus (P) [41], many studies have demonstrated that alum sludge could adsorb a number of heavy metals and semimetals from wastewaters and polluted soils, including $\mathrm{Cd}, \mathrm{Cr}$, $\mathrm{Co}, \mathrm{Cu}, \mathrm{Pb}, \mathrm{Hg}, \mathrm{Ni}, \mathrm{Zn}, \mathrm{Mo}, \mathrm{V}, \mathrm{Ga}, \mathrm{As}, \mathrm{Se}$, and B [26]. Moreover, considerable research has been carried out to reuse dewatered alum sludge as substrate in CWs due to its large specific surface area (60-300 $\mathrm{m}^{2} / \mathrm{g}$ ) and porous structure [41]. In particular, alum sludge has been successfully reused at first time for $\mathrm{H}_{2} \mathrm{~S}$ removal in a fixed-bed reactor, with the capacity of $374.2 \mathrm{mg} \mathrm{H}_{2} \mathrm{~S} \mathrm{~g}^{-1}$ [23]. Herein, it is highly promising and reasonable to employ alum sludge as the substrate in novel "odor-gas aerated" $\mathrm{CW}$ or biofilter for odor $\left(\mathrm{H}_{2} \mathrm{~S}\right)$ eliminating.

As such, it could be a "win-win" solution to integrate BF concept with aerated biofilter by using the existing available resource "waste gas" for biofilter's aeration. It could counteract the shortage of each technology (e.g., partially remedy the high operation costs of the aeration process and reducing the extra land requirement) to achieve dualgoals of simultaneous waste gas purification and the enhanced wastewater treatment. Moreover, efficient resources recycle/reuse and odor abatement remains the challenges for WWTPs worldwide. In particular, majority of WWTPs in China have been required to meet third-grade (GB3838-2002) surface water standard [39]. However, currently they are unable to meet the new guidelines. This proposed approach of using odor generated and collected from the WWTPs for biofilter aeration could be used for upgrading the existing WWTPs, by adding a series of novel "odor aerated" biofilters for ensuing effluent treatment as polishing stage in the existing plants to achieve enhanced wastewater efficiency and meanwhile for odor abatement. Hence, this study developed the alum sludge-based odor-gas aerated biofilter. It aims to remove the pollutants in wastewater and simultaneously to eliminate $\mathrm{H}_{2} \mathrm{~S}$ generated from wastewater treatment facility.

\section{Material and methods}

\subsection{Three columns setup and operation strategy}

Dewatered alum sludge cakes were obtained from the Carmaux water treatment plant, located in Tarn, France. The plant supplies 3014 $\mathrm{m}^{3}$ /day drinking water to 7,000 consumers, by treating reservoir water using aluminum chloride hydroxide sulfate (HYDREX 3531 Veolia, France) as a coagulant. The characterization of the alum sludge was found that the $\mathrm{Al}$ was $33 \%$, with the details are reported in Ren et al., [23].

The experiment (as illustrated in Fig. 1) was composed of three parallel columns constructed with identical plexiglass columns of diameter $15 \mathrm{~cm}$ and height $100 \mathrm{~cm}$. In each column, gravel $(15 \mathrm{~cm}$ depth) was filled into the bottom as the support medium, while $80 \mathrm{~cm}$ depth air-dried alum sludge cake (moisture content $63 \%$, particle size $3-6 \mathrm{~cm}$ ) was filled as the main wetland medium layer, which gives a total volume of $16.8 \mathrm{~L}$ with initial porosity of $42 \%$ (7 L liquid contained). Aeration of column 1 and 2 was supplied with a diffuser placed on the support (gravel) layer (10 cm high from the bottom) and controlled with an air flow meter. Before the trial was formally operated, three columns were seeded with activated sludge collected from a local municipal WWTP for two weeks.

Synthetic wastewater (prepared from tap water, containing the compounds of NaAC $480 \mathrm{mg} / \mathrm{L}, \mathrm{NH}_{4} \mathrm{Cl} 120 \mathrm{mg} / \mathrm{L}, \mathrm{KH}_{2} \mathrm{PO}_{4} 40 \mathrm{mg} / \mathrm{L}$, $\mathrm{CaCl}_{2} 15 \mathrm{mg} / \mathrm{L}, \mathrm{MgSO}_{4} 12 \mathrm{mg} / \mathrm{L}$, with the COD, TN, TP approximately of $300,30,10 \mathrm{mg} / \mathrm{L}$, respectively), was introduced by peristaltic pumps into the column from the top while effluent was drained from the bottom. Prior to the trial, determination of the optimal aeration strategies was carried out by applying minimum aeration times and aeration rates in column in order to achieve the highest TN removal efficiency. Preliminary results suggest that the best TN removal efficiency (85\%) was reached at the aeration time and rate of $4 \mathrm{~h} / \mathrm{d}$ and $20 \mathrm{~L} / \mathrm{h}$, respectively. Thus, the system was operated in batch mode and intermittently aerated four hours $(2 \mathrm{~h}+2 \mathrm{~h})$ per day at an airflow rate of $20 \mathrm{~L} / \mathrm{h}$ (i.e. filling influent at 8:00 am, first aeration period was from 8:30 to 10:30 and second aeration period was from $16: 30$ to $18: 30$ ). To simulate the waste gas, column 1 (Al-OAF) was intermittently "aerated" with steel gas cylinder containing $200 \mathrm{ppm} \mathrm{H}_{2} \mathrm{~S}$ based on air (a mixture of air and 200 ppm $\mathrm{H}_{2} \mathrm{~S}$ ). Column 2 (Al-AF) was intermittently aerated with compressed air from a compressor in the lab. Column 3 (Al-F) was un-aerated

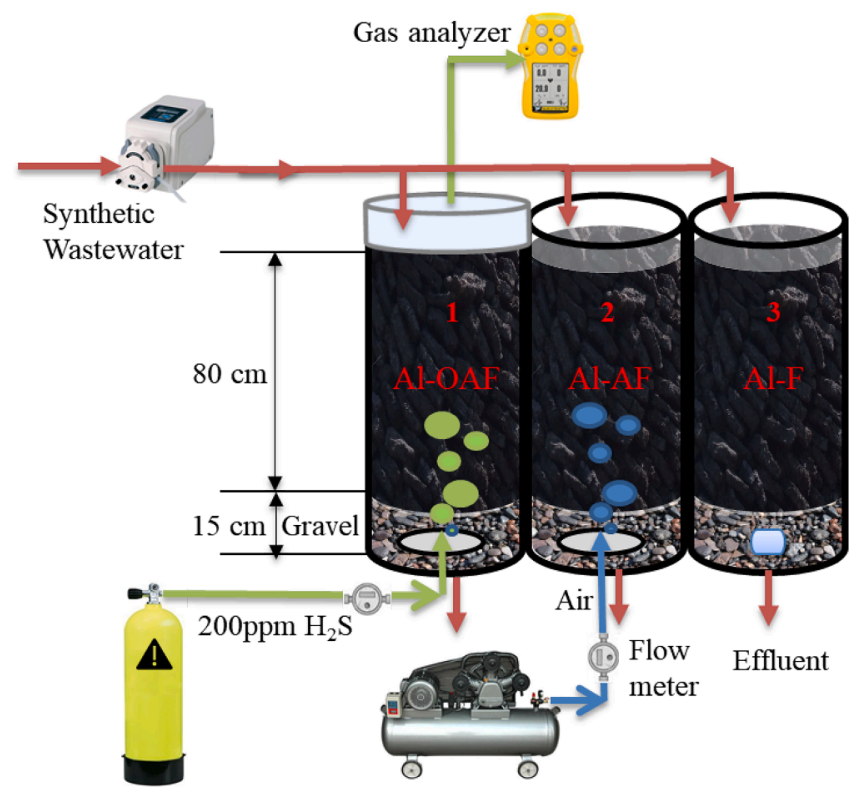

Fig. 1. Testing system of the three parallel columns. 
and served as a control. The experiment was then kept operation for six months under room temperature.

\subsection{Analysis and data interpretation}

Water samples were taken from the influent and effluent of the three columns at the same time (8:00 am) every 3 days. Samples were analyzed immediately for organic matter (as COD), TP, TN and ammonia-nitrogen $\left(\mathrm{NH}_{4}-\mathrm{N}\right)$. A Merck Nova 60 spectrophotometer was used to analyze COD; A Shimadzu VCPH 5050A was used for TN analysis; $\mathrm{NH}_{4}^{+}-\mathrm{N}$ was analyzed by ion chromatography (Dionex ICS 3000); TP were determined by inductively coupled plasma-atomic emission spectroscopy (ICP-AES) on a HORIBA Jobin Yvon Ultima 2. Scanning electron microscopy (SEM) (Philips XL30 ESEM apparatus, FEI Company) coupled with an energy-dispersive X-ray spectroscopy (EDX analysis) was employed for alum sludge/substrate analysis.

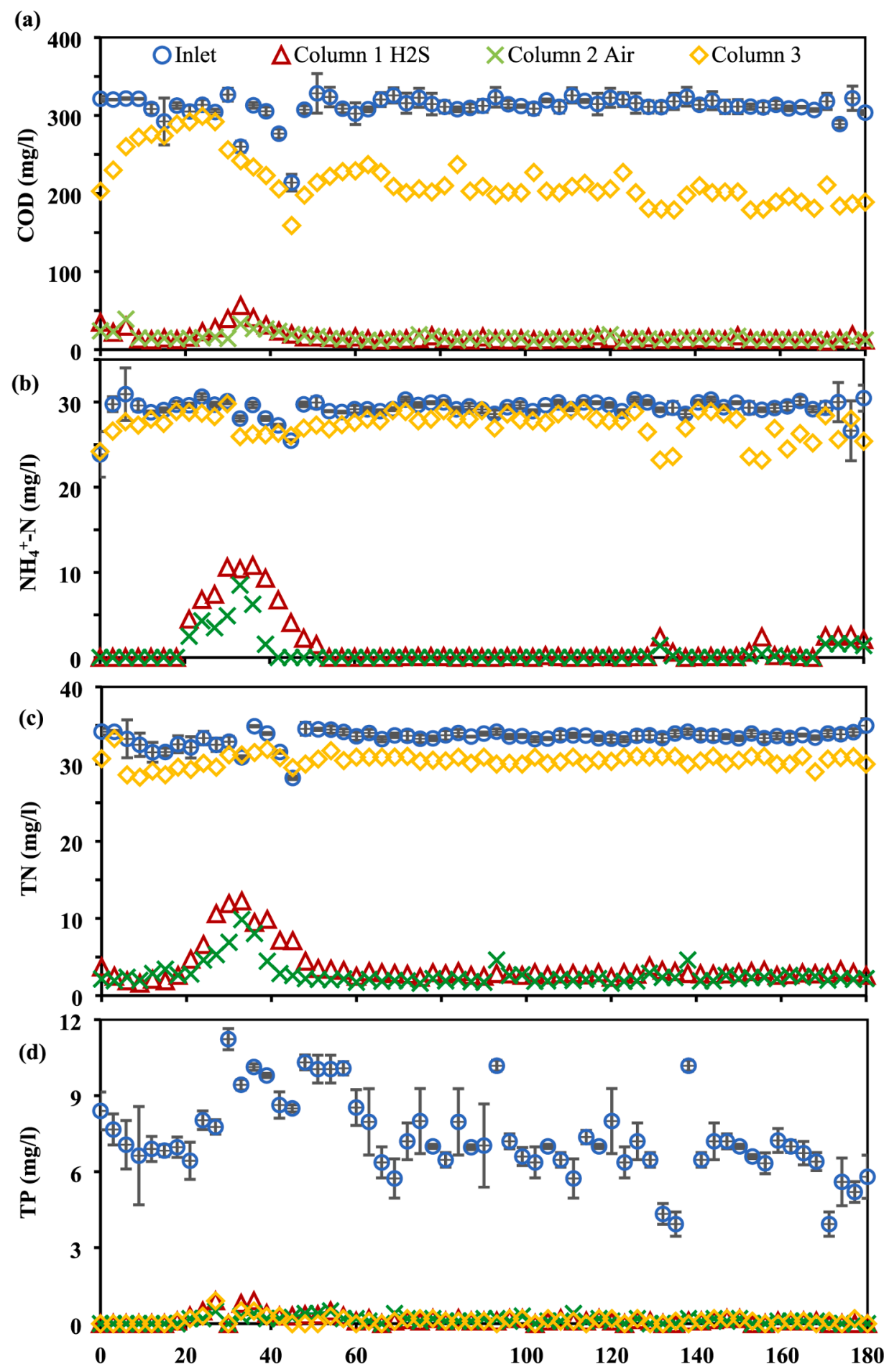

Fig. 2. Pollutants removal performance in three columns. 
To collect effluent $\mathrm{H}_{2} \mathrm{~S}$, a plexiglass cap (as shown in Fig. 1) with rubber seal ring inside to prevent the $\mathrm{H}_{2} \mathrm{~S}$ leakage was tightly covered on the column 1 (Al-OAF) during the aeration period. The output $\mathrm{H}_{2} \mathrm{~S}$ concentration was monitored and record every two minutes by using a gas analyzer from BW Technologies (Gas Alert QUATTRO). After the aeration, the cap was immediately removed to keep the surface water in contact with atmosphere. Pollutant removal efficiency (RE) for the trials was calculated as a cumulative percent removal between the influent and the effluent. $\mathrm{H}_{2} \mathrm{~S}$ loading rate $\left(\mathrm{LR}, \mathrm{g} \cdot\left(\mathrm{m}^{3} \cdot \mathrm{h}\right)^{-1}\right)$ and elimination capacity (EC, $g \cdot\left(\mathrm{m}^{3} \cdot \mathrm{h}\right)^{-1}$ ) was calculated by Eq. (1) and (2).

$L R=\frac{Q}{V} \times C_{\text {in }}$

$E C=\frac{Q}{V} \times\left(C_{\text {in }}-C_{\text {out }}\right)$

where $Q$ is the gas flow rate $\left(\mathrm{m}^{3} \cdot \mathrm{h}^{-1}\right), \mathrm{V}$ is the net bed volume $\left(\mathrm{m}^{3}\right), \mathrm{C}_{\text {in }}$ and $\mathrm{C}_{\text {out }}$ are the inlet and outlet $\mathrm{H}_{2} \mathrm{~S}$ concentrations, respectively $\left(\mathrm{mg} \cdot \mathrm{m}^{-3}\right)$.

\section{Results and discussion}

\subsection{Pollutants removal performance in three columns}

The COD removal performance of the three columns is shown in Fig. 2 (a). After one month's acclimatization, three parallel columns showed stable COD removal performance. The average effluent COD concentrations of column 1 (Al-OAF), 2 (Al-AF) and 3 (Al-F), which corresponds to the columns aerated with $\mathrm{H}_{2} \mathrm{~S}$, air and the blank column, were $17.27 \pm 8.51,15.99 \pm 5.19$ and $217.47 \pm 31.66 \mathrm{mg} / \mathrm{L}$, respectively. The COD removal performance in column 3 (Al-F) was not satisfied during the six-month trials. Previous studies clearly revealed that in un-aerated VFCWs the level of DO was low (0.12-1.3 mg/L) [10], and thus organic matter cannot be well oxidized and removed. Contrarily, it can be observed that intermittent aeration (column 1 and 2) significantly enhanced the COD removal by $92.1 \%$ and $92.6 \%$, respectively. This is due to the intermittent air supply creating a better aerobic environment, as organic compounds are degraded by bacteria $[29,15]$. It is worth to note that the COD removal performance of column 1 (Al-OAF) presents almost the same level with column 2 (Al-AF). It indicated that $\mathrm{H}_{2} \mathrm{~S}$ has limited influence on the COD effluent concentration as it can be observed that six-month average effluent COD concentration of column 1 (Al-OAF) was slightly higher (7\%) than that in column 2 (Al-AF).

$\mathrm{NH}_{4}-\mathrm{N}$ removal performance is presented in Fig. 2(b). The average $\mathrm{NH}_{4}-\mathrm{N}$ effluent concentrations of column1 (Al-OAF), 2 (Al-AF) and 3 (Al-F) were $1.45 \pm 2.98,0.60 \pm 1.66$ and $27.34 \pm 1.58 \mathrm{mg} / \mathrm{L}$, respectively. Nitrification converts $\mathrm{NH}_{4}-\mathrm{N}$ into $\mathrm{NO}_{3}-\mathrm{N}$ for eventual TN elimination. Nitrification often requires a relatively high DO concentration, thus the $\mathrm{NH}_{4}-\mathrm{N}$ removal performance in column 1 (Al-OAF) and 2 (Al$\mathrm{AF}$ ) were greater than column 3 (Al-F). It also reveals that the aeration strategy is successful, and the nitrification process was sufficient to convert $\mathrm{NH}_{4}-\mathrm{N}$ to $\mathrm{NO}_{2}-\mathrm{N}$ and $\mathrm{NO}_{3}-\mathrm{N}$. The TN removal performance of the three parallel columns is shown in Fig. 2(c). The average effluent TN concentrations of column 1 (Al-OAF), 2 (Al-AF) and 3 (Al-F) were 3.79 $\pm 2.44,2.75 \pm 1.55$ and $30.46 \pm 0.84 \mathrm{mg} / \mathrm{L}$, respectively. Lu et al. [18] showed that $\mathrm{N}$ transformations in the biofilter mainly include volatilization, ammonification, nitrification, denitrification and matrix adsorption. Liu et al. [17] states that different designs could achieve various $\mathrm{N}$ removal processing in VFCWs, and intermittent aeration could change $\mathrm{N}$ pathways when treating synthetic domestic wastewater.

In the un-aerated Al-F (column 3), the DO level was always low, resulted in negligible nitrification process. As a result, the TN removal performance was limited. Compared with the column 3 (Al-F), the intermitted aeration in column 1 (Al-OAF) and 2 (Al-AF) increased the TN removal of $87.6 \%$ and $91.0 \%$, respectively. The turbulence of data between day 27 and day 45 in Fig. 2 was likely due to the room temperature decreasing before the heat supply season. The trial started from October and the temperature was about $6-8{ }^{\circ} \mathrm{C}$ in the early November, which affects mass transfer and biological reactions. Furthermore, the relatively unstable organic loading (during day 27 and day 45) may have an important effect on the denitrification process, which also leads to a turbulence removal rate of TN. After this period, TN removal performance of three columns remains well and stable.

TP removal is illustrated in Fig. 2 (d). The average TP effluent concentrations in column 1 (Al-OAF), 2 (Al-AF) and 3 (Al-F) were $0.18 \pm$ $0.20,0.15 \pm 0.14$ and $0.13 \pm 0.16 \mathrm{mg} / \mathrm{L}$, respectively. The major processes responsible for $\mathrm{P}$ removal in CWs and biofilters are adsorption by the substrate, chemical precipitation, and assimilation into microbial and plant biomass [11]. Furthermore, precipitation can refer to the reaction of phosphate ions with metallic cations such as $\mathrm{Al}$, Ca or Fe, forming amorphous or poorly crystalline solids. Some important mineral precipitates in the wetland environment are: apatite, hydroxyl apatite, variscite, wavellite. In addition to direct chemical reaction, P can coprecipitate with other minerals, such as carbonate minerals, such as calcite (calcium carbonate).

From Fig. 2(d), all the columns performed equally well at removing $\mathrm{P}$ attributed to the $\mathrm{P}$ removing ability of the alum sludge, most likely $\mathrm{P}$ adsorption and precipitation reactions with the alum sludge. In most biofilters, it is often a challenge to achieve concurrent high removal efficiencies for $\mathrm{P}$ and organic matter. Therefore, the wetland substrate to own potential $\mathrm{P}$ adsorption ability is vital for concurrent $\mathrm{P}$ removal and high organic matter, i.e. COD, removal. That is why the dewatered alum sludge was used as main wetland substrate [41].

\subsection{Overall removal efficiency in three columns}

The six-month average removal efficiencies (RE, \%) of COD, TN, $\mathrm{NH}_{4}-\mathrm{N}$, TP in the three columns are shown in Fig. 3. The RE of COD in column 1 (Al-OAF), 2 (Al-AF) and 3 (Al-F) was $94.3 \pm 3.0,94.8 \pm 1.9$ and $30.2 \pm 11.0 \%$, respectively. Compared with the un-aerated Al-F (column 3), the introduction of $\mathrm{H}_{2} \mathrm{~S}$ and air into column 1 (Al-OAF) and 2 (Al-AF) greatly improved COD removal efficiency. Generally, the unaerated VFCWs and biofilters could achieve $61-80 \%$ of COD removal $[5,10,34]$. However, in this study the column 3 (Al-F) presented a relatively low RE of COD. This is possibly due to the single stage CW as the wastewater cannot have sufficient time to contact with the biofilm. Intermittently aerated with $\mathrm{H}_{2} \mathrm{~S}$ and air could achieve 64.1 and $64.6 \%$ additional RE of COD. In particular, no significant difference in COD removal was observed between column 1 (Al-OAF) and 2 (Al-AF). This demonstrates that $\mathrm{H}_{2} \mathrm{~S}$ aeration has no negative influence on the COD removal. From the literature, the average value of RE of COD in intensified CWs is estimated at $84 \pm 12 \%$ [10]. Obviously, $\mathrm{H}_{2} \mathrm{~S}$ aeration is a kind of intensification of CWs.

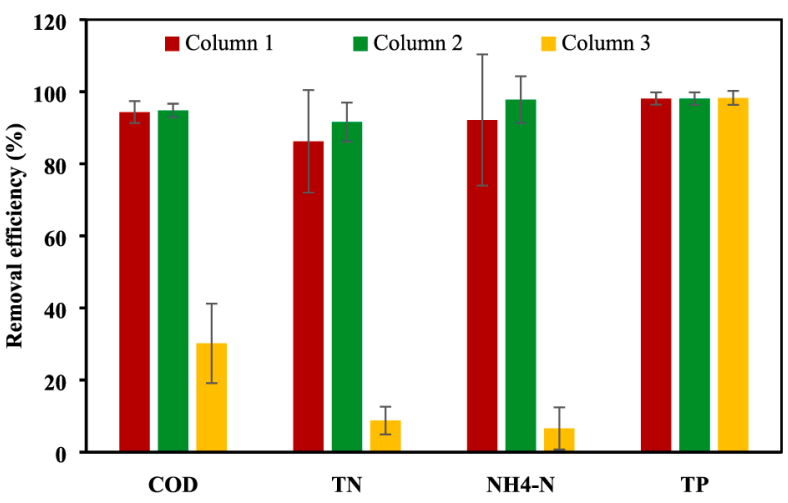

Fig. 3. Overall removal efficiency of $\mathrm{COD}, \mathrm{TN}, \mathrm{NH}_{4}-\mathrm{N}$ and $\mathrm{TP}$ in three columns. 
The TN RE of column 1 (Al-OAF), 2 (Al-AF) and 3 (Al-F) was $86.2 \pm$ $14.2,91.6 \pm 5.4$ and $8.8 \pm 3.8 \%$, respectively. This result indicates that the introduction of $\mathrm{H}_{2} \mathrm{~S}$ and air could effectively improve TN removal. Literature survey showed a large variation in $\mathrm{N}$ removal of un-aerated VFCWs (26-65\%) [10]. In this study, column 3 (Al-F) only presented a quite low average RE of $8.8 \pm 3.8 \%$, mainly due to the low DO level of batch operation with a negligible nitrification process. In column 1 (Al$\mathrm{OAF}$ ) and 2 (Al-AF), the additional TN RE was 77.4 and $82.8 \%$, respectively was achieved. Compared with the study reported by Fan et al. [5], additional removal of $64 \%$ of TN in an traditional intermittent aeration VFCW was obtained. Wu et al. [34] also reported that a $63 \%$ additional removal of TN was achieved in a VFCW with intermittent aeration fed with domestic wastewater. Thus, it indicated that the $\mathrm{H}_{2} \mathrm{~S}$ aeration in column 1 (Al-OAF) could achieved a high TN RE, even higher than the traditional intermittent aeration VFCWs. However, the six months average $\mathrm{RE}$ of TN in column 1 (Al-OAF) was $5.4 \%$ lower than the column 2 (Al-AF). This may be due to the long term $\mathrm{H}_{2} \mathrm{~S}$ feeding, and in the presents of microorganisms which could oxidize sulfides such as thiobacillus bacteria. Some of the reaction products (e.g., sulfates) could be converted into sulfuric acid in the wastewater, while sulfuric acid may inhibit microbial activity, resulted in a reducing TN removal [31]. More importantly, the current result was contrary with Zhang et al. [40] who conducted the trial of using waste gas for VFCW aeration. They pointed out that the best TN RE $(51.88 \pm 3.42 \%)$ was observed and the worse TN removal performance $(23.14 \pm 2.12 \%)$ was in the VFCW intermittently aerated with air. The reason may be from the different aeration strategies [30]. In this study intermittent aeration at an airflow rate of $20 \mathrm{~L} / \mathrm{h}$ for two cycles in a day was applied, while each cycle of 120 mins could successfully cerate the alternative nitrification-denitrification environment and thus facilitated the TN removal.

The $\mathrm{NH}_{4}-\mathrm{N} \mathrm{RE}$ of the three columns was $92.1 \pm 18.2,97.8 \pm 6.5$ and $6.6 \pm 5.9 \%$, respectively. In column 1 (Al-OAF) and 2 (Al-AF), the RE of $\mathrm{NH}_{4}-\mathrm{N}$ was over $90 \%$, indicating the functional nitrification process. However, in the un-aerated Al-F (column 3), the DO level was always low, causing an anaerobic environment, and thus may have negligible nitrification. Moreover, the six-month average $\mathrm{RE}$ of $\mathrm{NH}_{4}-\mathrm{N}$ in column 1 (Al-OAF) was slightly (5.7\%) lower than in column 2 (Al-AF). This may be due to the long-term biological $\mathrm{H}_{2} \mathrm{~S}$ degrading processes generating sulfuric acid to inhibit microbial activity. This is contrary to Zhang et al. [40], who demonstrated a better nitrification performance in a waste gas aerated system. However, Zhang et al. [40] used a lower $\mathrm{H}_{2} \mathrm{~S}$ concentration $\left(0.0045 \pm 0.0006 \mathrm{mg} / \mathrm{m}^{3}\right)$, which comes from a sequencing batch reactor (SBR). The low concentration could be used by microorganisms for reproductive growth and enhanced nitrification.

The average TP RE of the three columns was $98.1 \pm 1.7$, $98.1 \pm 1.7$ and $98.3 \pm 1.9 \%$, respectively. No significant differences were found among the three columns. Likewise, Ilyas and Masih [11] found that artificial aeration did not have a significant influence on $\mathrm{P}$ removal as $\mathrm{P}$ removal in alum sludge based-CWs depends mainly on adsorption of the reactive substrate, i.e., alum sludge [41]. Previous studies suggest that in all types of CWs, TP removal varied between 40 and $60 \%$ with removed load ranging between 45 and $75 \mathrm{~g} \mathrm{P} \mathrm{m}^{2}$ /year depending on CW types and flow loading [20]. In the current study, the superior TP removal performance was attributed by the alum sludge, which has been extensively investigated as a media for TP removal from various CWs, the $\mathrm{P}$ removal mechanisms lies in the various chemical composition of alum sludge, specifically its content of $\mathrm{Ca}, \mathrm{Al}$ or $\mathrm{Fe}$, three elements that can react with $\mathrm{P}$ under different environmental conditions [36].

\section{3. $\mathrm{H}_{2} \mathrm{~S}$ removal efficiency}

Previous studies have shown that acclimatization could shorten or even eliminate the biofilter start-up phase [37]. Thus, before the $\mathrm{H}_{2} \mathrm{~S}$ was introduced to column 1 (Al-OAF), air was supplied at a flow rate of $20 \mathrm{~L} / \mathrm{h}$ and $4 \mathrm{~h}$ per day for two weeks to acclimatize and develop the biofilm (The same manner was applied for column 2).
After two weeks' acclimatization, $200 \mathrm{ppm} \mathrm{H}_{2} \mathrm{~S}$ based on air was introduced into column 1 (Al-OAF) at the same flow rate of $20 \mathrm{~L} / \mathrm{h}$. The $\mathrm{H}_{2} \mathrm{~S}$ concentrations in the outlet of column 1 (Al-OAF) were continuously recorded during the $4 \mathrm{~h}$ aeration period every day. As illustrated in Fig. 4, H2S was completely removed during the " $2 \mathrm{~h}+2 \mathrm{~h}$ " aeration periods each day. In particular, this complete $\mathrm{H}_{2} \mathrm{~S}$ removal efficiency was keeping stable on each day over the six-month trial period. The loading rate $(100 \%$ removal) as well as elimination capacity of column 1 (Al-OAF) was $867.3 \mathrm{~g} \cdot\left(\mathrm{m}^{3} \cdot \mathrm{h}\right)^{-1}$. This capacity was significantly higher than that of Zhang et al., [40]. This is likely due to an optimized intermediate aeration strategy $(2 \mathrm{~h}+2 \mathrm{~h})$, which could create a proper aerobic environment for the $\mathrm{H}_{2} \mathrm{~S}$ biodegradation process.

\section{4. $\mathrm{H}_{2} \mathrm{~S}$ removal mechanisms}

In this study, the Al-OAF (column 1) acted as a "biofilter" to remove $\mathrm{H}_{2} \mathrm{~S}$. Indeed, microorganisms are the "engines" of CW as well as "biofilter" since the pollutant removal was highly depending on their activity. As shown in Fig. 5, the microbial degradation was occurred when $\mathrm{H}_{2} \mathrm{~S}$ reaches the wastewater and specially biofilm. In fact, biofilm is a mixture of bacteria, fungi, yeasts, ciliated protozoa, amoebae, nematodes, algae and water [25]. In the present study, various bacteria have been contributed in bioprocesses to decompose $\mathrm{H}_{2} \mathrm{~S}$ to elemental sulfur based on their functions as biocatalysts, such as phototrophic bacteria (also known as green sulfur bacteria), chemotrophs and Xanthomonas [37]. In the literature [31,38], bioconversion of $\mathrm{H}_{2} \mathrm{~S}$ in presence of oxygen as a main electron acceptor can be described by Eqs. (3)-(5). In these reactions, $\mathrm{H}_{2} \mathrm{~S}$ was oxidized by microbes and generating the odorless compounds such as elemental sulfur and sulfate. In particular, Fig. 5 (a) and (b) illustrate alum sludge before and after the trial, respectively. Large amount of $S$ was observed on the surface of alum sludge after six-month trial. It indicated that the biodegradation process occurs on the surface (biofilm) of the alum sludge.

$\mathrm{H}_{2} \mathrm{~S}+0.5 \mathrm{O}_{2} \rightarrow \mathrm{S}^{0}+\mathrm{H}_{2} \mathrm{O}$

$\mathrm{S}_{0}+1.5 \mathrm{O}_{2}+\mathrm{H}_{2} \mathrm{O} \rightarrow \mathrm{SO}_{4}^{2-}+82 \mathrm{H}^{+}$

$\mathrm{H}_{2} \mathrm{~S}+2 \mathrm{O}_{2} \rightarrow \mathrm{SO}_{4}^{2-}+2 \mathrm{H}^{+}$

The microbes could also use the intermediate biodegradation products of $\mathrm{H}_{2} \mathrm{~S}$ (e.g., $\mathrm{HS}^{-}$and $\mathrm{S}^{2-}$ ) as energy sources. Moreover, chemotrophs could use organic and inorganic compounds $\left(\mathrm{CO}_{2}\right)$ as the carbon source to oxidize $\mathrm{H}_{2} \mathrm{~S}$ and produce metabolic energy and new cell materials. In addition, the removal of sulfide could also be contributed by phototrophic bacteria. The biocatalytic reaction was descripted in Eq. (6). In strictly anaerobic conditions, in the presence of light, $\mathrm{CO}_{2}$ and inorganic nutrients, sulfide was converted to elemental sulfur by green sulfur bacteria [25].

$2 \mathrm{nH}_{2} \mathrm{~S}+\mathrm{nCO}_{2}+\mathrm{hv} \rightarrow 2 \mathrm{nS}+\mathrm{nCH}_{2} \mathrm{O}$

Furthermore, heterotrophic (e.g., Thiobacillus sp.) bacterial biodegradation of $\mathrm{H}_{2} \mathrm{~S}$ could also exist. The end product (sulfates) was generated through the intermittent polysulfides via bacterial degradation [13].

The biodegradation of $\mathrm{H}_{2} \mathrm{~S}$ occurs under aerobic conditions, which means $\mathrm{O}_{2}$ could acted as an electron acceptor. However, in anoxic conditions the biodegradation of $\mathrm{H}_{2} \mathrm{~S}$ could also occur when nitrate $\left(\mathrm{NO}^{3}\right.$ ${ }^{-}$) was used as an electron acceptor instead of oxygen [31]. This process (as described in Eq. (7)) results in generations of sulfate and elemental sulfur, while nitrate is reduced to nitrogen and nitrite. However, the anoxic biodegradation of $\mathrm{H}_{2} \mathrm{~S}$ and reduction of $\mathrm{NO}^{3-}$ are a complex process. It highly depends on the operational parameters, such as N/S ratio.

$12 \mathrm{H}_{2} \mathrm{~S}+15 \mathrm{NO}_{3}^{-} \rightarrow 6 \mathrm{~S}^{0}+6 \mathrm{SO}_{4}^{2-}+5 \mathrm{~N}_{2}+5 \mathrm{NO}_{2}^{-}+9 \mathrm{H}_{2} \mathrm{O}+2 \mathrm{OH}^{-}+4 \mathrm{H}^{+}$

In general, sulfate $\left(\mathrm{SO}_{4}^{2-}\right)$ is the main sulfur species that is formed 


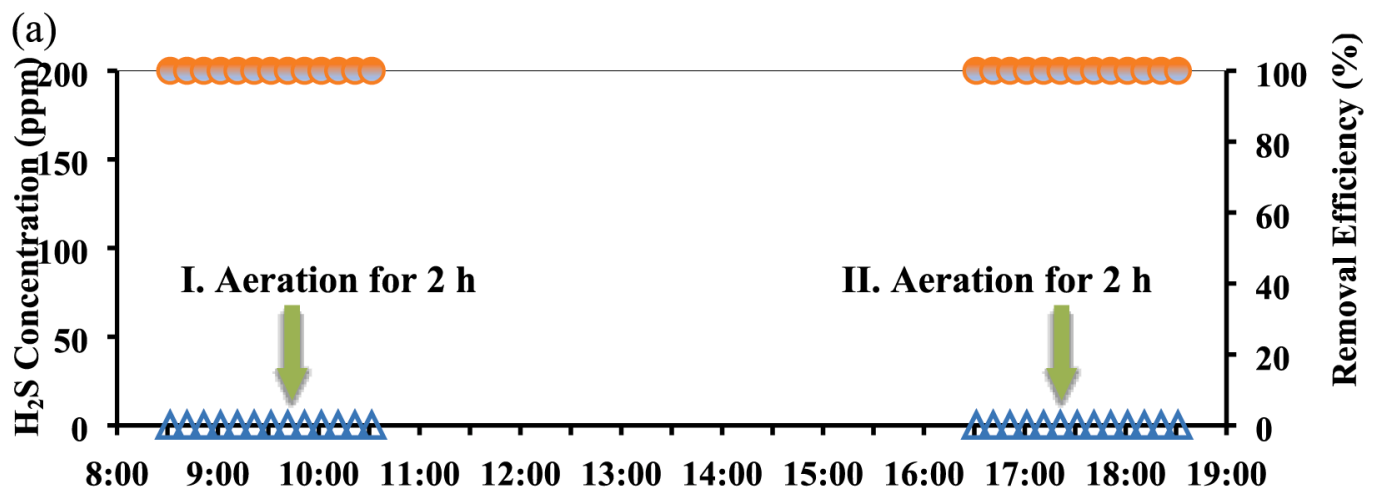

(b)

Time

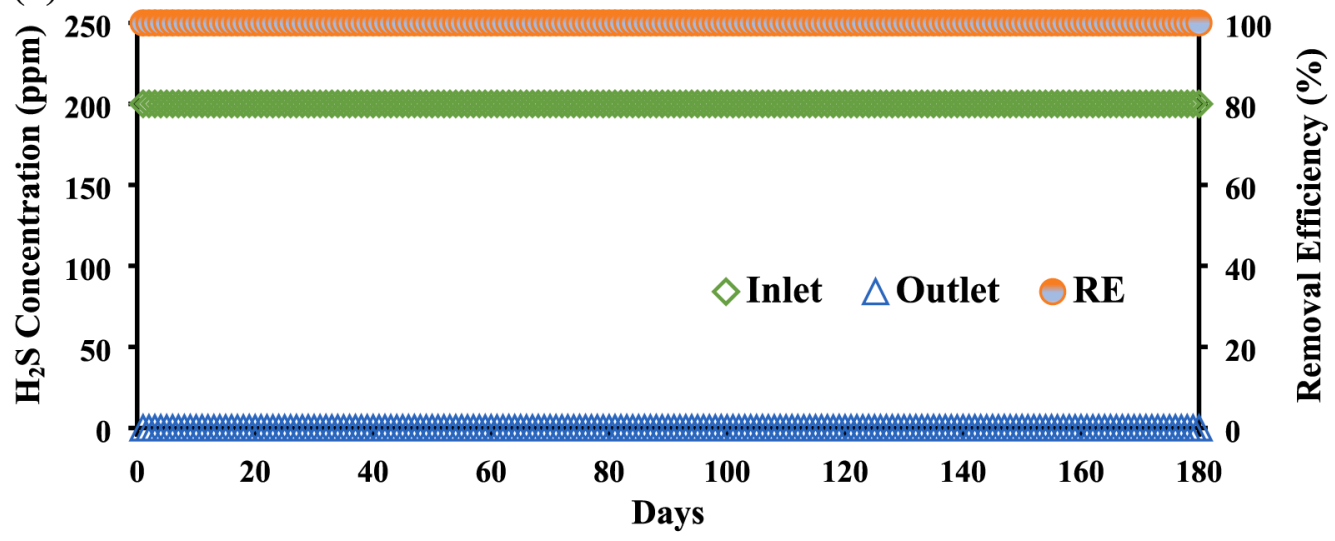

Fig. 4. Online analysis of $\mathrm{H}_{2} \mathrm{~S}$ effluent and removal efficiency: (a) daily $\mathrm{H}_{2} \mathrm{~S}$ data, (b) overall $\mathrm{H}_{2} \mathrm{~S}$ removal performance.

during the bioconversion of $\mathrm{H}_{2} \mathrm{~S}$ [4]. It has also been reported by Vikrant et al. [31] that the accumulation of sulfate may inhibit microbial activity and decrease the mass transfer rate of $\mathrm{H}_{2} \mathrm{~S}$ into the biofilm (due to reduced $\mathrm{pH}$ ), reducing removal efficiency significantly. However, the effluent from the Al-OAF (column 1) can mitigate $\mathrm{SO}_{4}^{2-}$ accumulation problems and also be effective to avoid the inhibitory effect caused by $\mathrm{SO}_{4}^{2-}$ since the $\mathrm{SO}_{4}^{2-}$ is washed out by the effluent. Moreover, the end products of $\mathrm{H}_{2} \mathrm{~S}$ biodegraded processes (sulfur or sulfate) are nonhazardous and ecology safe [16].

Besides the biodegradation process, $\mathrm{H}_{2} \mathrm{~S}$ sorption by alum sludge substrate is also a vital route for $\mathrm{H}_{2} \mathrm{~S}$ removal. In a recent study [23], alum sludge have been demonstrated as an efficient sorbent for $\mathrm{H}_{2} \mathrm{~S}$ removal in a fixed-bed column. The various flow rates, bed depth (mass of sorbent), breakthrough behavior simulation and modeling were investigated. In particular, the complex mechanisms behind $\mathrm{H}_{2} \mathrm{~S}$ sorption onto alum sludge of a three-step (sorption-dissociation-oxidation) process were proposed. Firstly, alum sludge has a microporous structure and relatively great surface area $\left(\mathrm{S}_{\mathrm{p}}(\mathrm{BET})=238 \mathrm{~m}^{2} / \mathrm{g}\right)$. Furthermore, due to the presence of various reactive sites (as shown in Fig. 5), e.g., carbon and metal oxides, $\mathrm{H}_{2} \mathrm{~S}$ molecules are dissociated by these active sites into $\mathrm{HS}^{-}$and $\mathrm{H}^{+}$when $\mathrm{H}_{2} \mathrm{~S}$ reaches the alum sludge surface and micropores. On the other hand, basic $\mathrm{pH}$ of alum sludge $(\mathrm{pH}=10)$ could facilitated the dissociation of $\mathrm{H}_{2} \mathrm{~S}$ and neutralize the acidification of alum sludge surface. Thereafter, the oxidation process with oxygenated organic and inorganic species leads to the formation of sulphate (Fig. 5).

Herein, the proposed $\mathrm{H}_{2} \mathrm{~S}$ removal mechanisms of column 1 (Al-OAF) lies in a complex reaction of biodegradation as well as a sorption process by the substrate (alum sludge). Biofilm and the suspended microorganisms in the wastewater act as powerful "engine" for $\mathrm{H}_{2} \mathrm{~S}$ conversion. Alum sludge also provided a proper media for $\mathrm{H}_{2} \mathrm{~S}$ sorption process.

\section{Perspective}

Upgrading the existing WWTPs (e.g., improving the effluent quality to meet the updated standard and abating the unpleasant odor) is more difficult than building a new plant. This is due to the lack of practical experience worldwide as well as the variation of the wastewater qualities, treatment process and local circumstances [9]. Building the effluent polishing or post-treatment (tertiary treatment) unit is one of the main upgrading options. It could minimize the interruptions in the daily operation of WWTPs and easy to implement. In especially, using biofilters or CWs as the polishing unit for WWTPs upgrading has become more favorable due to the low cost, simple operation \& maintenance, natural landscape and biodiversity merits. Zhu et al. [43] reported the use of a large-scale vertical-flow CWs as the polishing unit at the end of WWTP in Henan, China. Results of 14 months study showed that average removals of $40.05 \% \mathrm{COD}, 45.47 \% \mathrm{NH}_{4}-\mathrm{N}, 62.55 \% \mathrm{TP}, 55.53 \% \mathrm{TN}$ and $57.20 \%$ TSS were achieved. Cao et al. [3] also states that a WWTP in China has been upgraded with the recycled concrete aggregate-based large-scale horizontal subsurface flow CWs. Indeed, China has faced urgent demand in large scale of existing WWTPs upgrading. To control the water environment in rivers, lakes and other surface water bodies, the current Chinese "National Standards for Environmental Quality of Surface Water (GB3838-2002)" requires the effluent COD $\leq 30 \mathrm{mg} / \mathrm{L}$, $\mathrm{NH}_{3}-\mathrm{N} \leq 1.5 \mathrm{mg} / \mathrm{L}, \mathrm{TP} \leq 0.1 \mathrm{mg} / \mathrm{L}$. By June 2018, there are 5300 WWTPs across China, the upgrading of such large number of WWTPs is a great challenge while large scale CWs systems have been proposed as principal process [33]. Wei et al. [32] reported five projects of WWTPs upgrading with CWs in China (i.e. by adding various CWs for terminal effluent treatment). However, few studies concern about odor treatment by using CWs for WWTPs upgrading.

Although alum sludge based-CWs have been intensively studied in recent years, to the best of our knowledge, this is the first time to use the alum sludge-based biofilter for dual goals of $\mathrm{H}_{2} \mathrm{~S}$ or odor gas abatement 

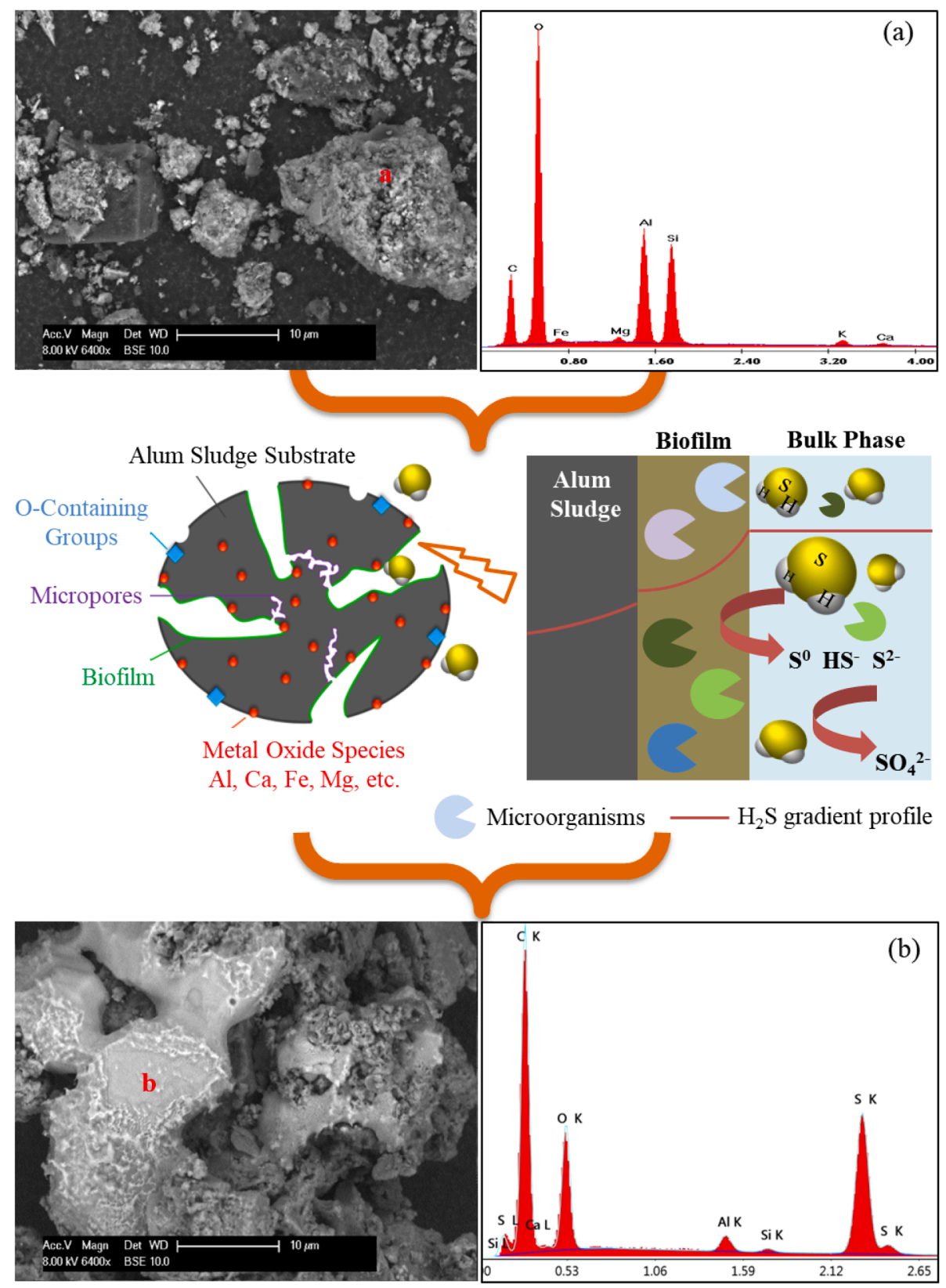

Fig. 5. SEM-EDX data and proposed $\mathrm{H}_{2} \mathrm{~S}$ removal mechanisms, (a) raw alum sludge, (b) alum sludge substrate from column 1 after six-month's trial.

and wastewater treatment. The novel technical strategy can be illustrated in Fig. 6. It has demonstrated that the alum sludge owns features of high $\mathrm{P}$ adsorption (over $98 \%$ ), ability of $\mathrm{H}_{2} \mathrm{~S}$ adsorption while biofilm developed on the alum sludge as wetland substrate owns capacity to have bio-reaction with $\mathrm{H}_{2} \mathrm{~S}$. In particular, the outstanding TP removal performance (over 98\%) of alum sludge could ensure that the effluent concentration of the upgraded WWTP complies with the strict discharge standard (TP $<0.1 \mathrm{mg} / \mathrm{L}$ in GB3838-2002). Thus, the single biological $\mathrm{P}$ removal process cannot fulfill this requirement. A combination of biological P removal with tertiary treatment should be applied under this circumstance. The current study opens a technical option for the WWTPs upgrading of using a "waste" by-product (alum sludge) from water industry as a raw material in biofilters for effluent polishing while for odor gas (generated from the WWTPs) purification. No doubt, the importance of this study will help the WWTPs not only for water quality improvement, but also for waste gas purification in the ensuing large-scale upgrading engineering practice.

However, this is an inaugurating study to demonstrate the "dual- goals" of upgrading approach, while only single odorant $\left(\mathrm{H}_{2} \mathrm{~S}\right)$ was tested. The real waste gas generated from wastewater treatment process and sludge treatment facilities in WWTPs is far more complicated than $\mathrm{H}_{2} \mathrm{~S}$. Even if $\mathrm{H}_{2} \mathrm{~S}$ was completely removed in the Al-OAF in this study, WWTPs could release various volatile organic sulfur compounds (VOSCs) and inorganic sulfur compounds. Nitrogenous compounds and volatile fatty acids (VFAs) are also potential sources of odor. Odorous volatile aromatic compounds (OVACs), such as toluene, ethylbenzene, styrene, p-cresol, indole and skatole, have been identified from stored biosolids while the treatment of biosolids/sludge could form different kind of odor-causing compounds [7]. The concentrations of those odorants account in a wide range depending on the nature of WWTPs. Obviously, those kinds of odorants with different concentrations need further investigation in the ensuing study.

\section{Conclusions}

This study developed a novel alum sludge-based odor-gas aerated 


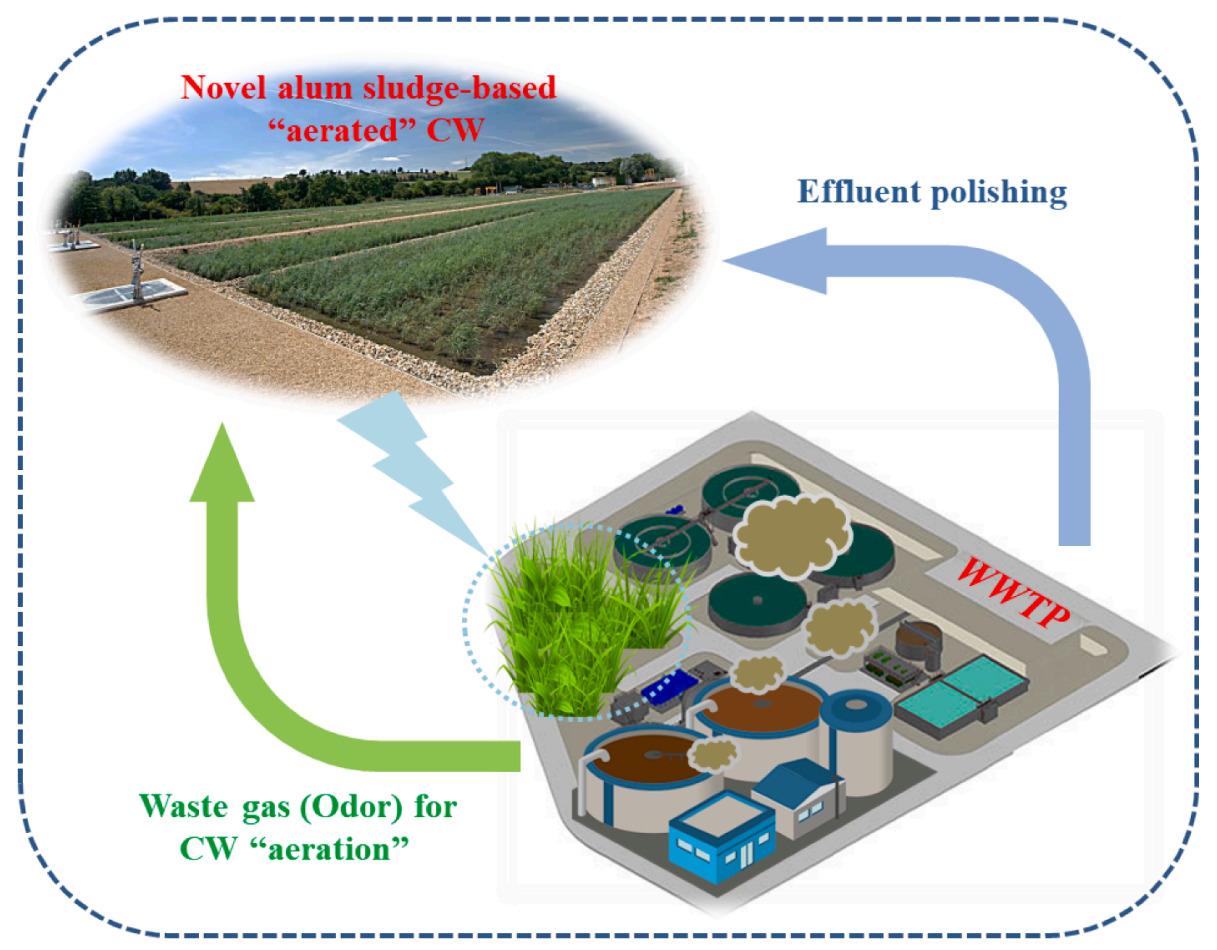

Fig. 6. Conceptual strategy of WWTP upgrading with novel alum sludge-based odor gas "aerated" CWs or biofilter system.

biofilter, aimed to provide an effective approach to simultaneously enhance overall pollutants removal in wastewater and purify $\mathrm{H}_{2} \mathrm{~S}$. Through the six-month trial, the high removal efficiency of TP ( $>98 \%)$ was achieved due to sorption onto the alum sludge, while $\mathrm{H}_{2} \mathrm{~S}$ was completed removed (100\%). The introduction of $\mathrm{H}_{2} \mathrm{~S}$ and air for $\mathrm{CW}$ aeration could significantly enhance the removal efficiency of COD and TN compared with an unaerated Al-F. More interestingly, there was no difference regarding the COD and TN removal performances between the " $\mathrm{H}_{2} \mathrm{~S}$ aerated" and air aerated Al-F. The data suggest that intermittently aerated $\mathrm{Al}-\mathrm{OAF}$ using $\mathrm{H}_{2} \mathrm{~S}$ would be a potential "wiser choice" to intensify pollutant removal performance for wastewater and odor gas purification. This has great potential in China for large scale WWTPs upgrading. However, further studies are suggested to determine: (a) the metabolic process and microbial community involved in the elimination of $\mathrm{H}_{2} \mathrm{~S}$; (b) their potential to remove other pollutants such as $\mathrm{NH}_{3}$ and VOCs from the WWTP odor stream; and (c) the application of this novel $\mathrm{Al}-\mathrm{OAF}$ in full-scale and long-term system.

\section{Declaration of Competing Interest}

The authors declare that they have no known competing financial interests or personal relationships that could have appeared to influence the work reported in this paper.

\section{Acknowledgements}

The first author greatly acknowledges RAPSODEE Research Centre (CNRS UMR 5302), France for the financial and technological support. This study also jointly supported by the Fundamental Research Funds for the Central Universities, CHD 300102291302.

\section{References}

[1] C. Alfonsín, R. Lebrero, J.M. Estrada, R. Muñoz, N.J.R.(. Kraakman, G. Feijoo, M T. Moreira, Selection of odour removal technologies in wastewater treatment plants: a guideline based on Life Cycle Assessment, J. Environ. Manage. 149 (2015) 77-84.

[2] K. Barbusinski, K. Kalemba, D. Kasperczyk, K. Urbaniec, V. Kozik, Biological methods for odor treatment - A review, J. Clean. Prod. 152 (2017) 223-241.
[3] Z. Cao, L.u. Zhou, Z. Gao, Z. Huang, X. Jiao, Z. Zhang, K. Ma, Z. Di, Y.u. Bai, Comprehensive benefits assessment of using recycled concrete aggregates as the substrate in constructed wetland polishing effluent from wastewater treatment plant, J. Clean. Prod. 288 (2021) 125551, https://doi.org/10.1016/j. jclepro. 2020.125551.

[4] J. Das, E.R. Rene, C. Dupont, A. Dufourny, J. Blin, E.D. van Hullebusch, Performance of a compost and biochar packed biofilter for gas-phase hydrogen sulfide removal, Bioresour. Technol. 273 (2019) 581-591.

[5] J. Fan, W. Wang, B.o. Zhang, Y. Guo, H.H. Ngo, W. Guo, J. Zhang, H. Wu, Nitrogen removal in intermittently aerated vertical flow constructed wetlands: Impact of influent COD/N ratios, Bioresour. Technol. 143 (2013) 461-466.

[6] A.I. Freeman, B.W.J. Surridge, M. Matthews, M. Stewart, P.M. Haygarth, New approaches to enhance pollutant removal in artificially aerated wastewater treatment systems, Sci. Total Environ. 627 (2018) 1182-1194.

[7] Y. Gruchlik, L. Fouché, C.A. Joll, A. Heitz, Use of alum for odor reduction in sludge and biosolids from different wastewater treatment processes, Water Environ. Res. 89 (12) (2017) 2103-2112.

[8] J. Hou, X. Wang, J. Wang, L. Xia, Y. Zhang, D. Li, X. Ma, Pathway governing nitrogen removal in artificially aerated constructed wetlands: Impact of aeration mode and influent chemical oxygen demand to nitrogen ratios, Bioresour. Technol. 257 (2018) 137-146.

[9] K. Hu, Q.L. Zhao, W. Chen, W. Wang, F. Han, X.H. Shen, Appropriate technologies for upgrading wastewater treatment plants: methods review and case studies in China, J. Environ. Sci. Health Part A 53 (14) (2018) 1207-1220.

[10] H. Ilyas, I. Masih, The performance of the intensified constructed wetlands for organic matter and nitrogen removal: a review, J. Environ. Manage. 198 (2017) 372-383.

[11] H. Ilyas, I. Masih, The effects of different aeration strategies on the performance of constructed wetlands for phosphorus removal, Environ. Sci. Pollut. Res. 25 (6) (2018) 5318-5335.

[12] B. Ji, Y. Zhao, A. Esteve-Núñez, R. Liu, Y. Yang, A. Nzihou, Y. Tai, T. Wei, C. Shen, Y. Yang, B. Ren, X. Wang, Ya'e Wang, Where do we stand to oversee the coronaviruses in aqueous and aerosol environment? Chem. Eng. J. 413 (2021) 127522, https://doi.org/10.1016/j.cej.2020.127522.

[13] X. Jiang, J.H. Tay, Removal mechanisms of H2S using exhausted carbon in biofiltration, J. Hazard. Mater. 185 (2-3) (2011) 1543-1549.

[14] R. Lebrero, L. Bouchy, R. Stuetz, R. Muñoz, Odor assessment and management in wastewater treatment plants: a review, Crit. Rev. Environ. Sci. Technol. 41 (10) (2011) 915-950.

[15] X. Li, W. Zhu, G. Meng, C. Zhang, R. Guo, Efficiency and kinetics of conventional pollutants and tetracyclines removal in integrated vertical-flow constructed wetlands enhanced by aeration, J. Environ. Manage. 273 (2020) 111120, https:// doi.org/10.1016/j.jenvman.2020.111120.

[16] S. Lin, H.R. Mackey, T. Hao, G. Guo, M.C.M. van Loosdrecht, G. Chen, Biological sulfur oxidation in wastewater treatment: a review of emerging opportunities, Water Res. 143 (2018) 399-415.

[17] F.-F. Liu, J. Fan, J. Du, X. Shi, J. Zhang, Y. Shen, Intensified nitrogen transformation in intermittently aerated constructed wetlands: removal pathways and microbial response mechanism, Sci. Total Environ. 650 (2019) 2880-2887. 
[18] J. Lu, Z. Guo, Y. Kang, J. Fan, J. Zhang, Recent advances in the enhanced nitrogen removal by oxygen-increasing technology in constructed wetlands, Ecotoxicol. Environ. Saf. 205 (2020) 111330, https://doi.org/10.1016/j.ecoenv.2020.111330.

[19] G. Maltais-Landry, R. Maranger, J. Brisson, F. Chazarenc, Nitrogen transformations and retention in planted and artificially aerated constructed wetlands, Water Res. 43 (2) (2009) 535-545.

[20] L.A. Nuamah, Y. Li, Y. Pu, A.S. Nwankwegu, Z. Haikuo, E. Norgbey, P. Banahene, R. Bofah-Buoh, Constructed wetlands, status, progress, and challenges. The need for critical operational reassessment for a cleaner productive ecosystem, J. Clean. Product. 269 (2020) 122340, https://doi.org/10.1016/j.jclepro.2020.122340.

[21] I. Omri, F. Aouidi, H. Bouallagui, J.-J. Godon, M. Hamdi, Performance study of biofilter developed to treat H2S from wastewater odour, Saudi J. Biol. Sci. 20 (2) (2013) 169-176.

[22] D. Parde, A. Patwa, A. Shukla, R. Vijay, D.J. Killedar, R. Kumar, A review of constructed wetland on type, technology and treatment of wastewater, Environ. Technol. Innovat. 101261 (2020).

[23] B. Ren, N. Lyczko, Y. Zhao, A. Nzihou, Alum sludge as an efficient sorbent for hydrogen sulfide removal: experimental, mechanisms and modeling studies, Chemosphere 248 (2020) 126010, https://doi.org/10.1016/j. chemosphere.2020.126010.

[24] B. Ren, Y. Zhao, N. Lyczko, A. Nzihou, Current status and outlook of odor removal technologies in wastewater treatment plant, Waste Biomass Valorization 10 (6) (2019) 1443-1458.

[25] Z. Shareefdeen, A. Singh (Eds.), Biotechnology for Odor and Air Pollution Control, Springer Berlin Heidelberg, Berlin, Heidelberg, 2005.

[26] C. Shen, Y. Zhao, W. Li, Y. Yang, R. Liu, D. Morgen, Global profile of heavy metals and semimetals adsorption using drinking water treatment residual, Chem. Eng. J. 372 (2019) 1019-1027.

[27] A.I. Stefanakis, M. Bardiau, D. Trajano, F. Couceiro, J.B. Williams, H. Taylor, Presence of bacteria and bacteriophages in full-scale trickling filters and an aerated constructed wetland, Sci. Total Environ. 659 (2019) 1135-1145.

[28] A. Talaiekhozani, M. Bagheri, A. Goli, M.R. Talaei Khoozani, An overview of principles of odor production, emission, and control methods in wastewater collection and treatment systems, J. Environ. Manage. 170 (2016) 186-206.

[29] S. Tang, Y. Liao, Y. Xu, Z. Dang, X. Zhu, G. Ji, Microbial coupling mechanisms of nitrogen removal in constructed wetlands: a review, Bioresour. Technol. 314 (2020) 123759, https://doi.org/10.1016/j.biortech.2020.123759.

[30] B. Tunçsiper, Nitrogen removal in an aerobic gravel filtration-sedimentation pondconstructed wetland-overland flow system treating polluted stream waters: effects of operation parameters, Sci. Total Environ. 746 (2020) 140577, https://doi.org/ 10.1016/j.scitotenv.2020.140577.

[31] K. Vikrant, S.K. Kailasa, D.C.W. Tsang, S.S. Lee, P. Kumar, B.S. Giri, R.S. Singh, K.H. Kim, Biofiltration of hydrogen sulfide: Trends and challenges, J. Clean. Prod. 187 (2018) 131-147.
[32] J. Wei, M. Zhao, W. Liu, L. Kong, X. Zhou, H. Zheng, Development status of constructed wetland (CWs) for treatment of terminal effluent of wastewater treatment plants (WWTPs) in China, China Water Wastewater 35 (2) (2019) 29-33 (In Chinese).

[33] C. Wu, Y. Li, Y. Zhou, Z. Li, S. Zhang, H. Liu, Upgrading the Chinese biggest petrochemical wastewater treatment plant: Technologies research and full scale application, Sci. Total Environ. 633 (2018) 189-197.

[34] H. Wu, J. Fan, J. Zhang, H.H. Ngo, W. Guo, Z. Hu, S. Liang, Decentralized domestic wastewater treatment using intermittently aerated vertical flow constructed wetlands: impact of influent strengths, Bioresour. Technol. 176 (2015) 163-168.

[35] S. Wu, P. Kuschk, H. Brix, J. Vymazal, R. Dong, Development of constructed wetlands in performance intensifications for wastewater treatment: a nitrogen and organic matter targeted review, Water Res. 57 (2014) 40-55.

[36] Y. Yang, Y. Zhao, R. Liu, D. Morgan, Global development of various emerged substrates utilized in constructed wetlands, Bioresour. Technol. 261 (2018) $441-452$.

[37] J. Yuan, L. Du, S. Li, F. Yang, Z. Zhang, G. Li, G. Wang, Use of mature compost as filter media and the effect of packing depth on hydrogen sulfide removal from composting exhaust gases by biofiltration, Environ. Sci. Pollut. Res. 26 (4) (2019) 3762-3770.

[38] D. Zak, M. Hupfer, A. Cabezas, G. Jurasinski, J. Audet, A. Kleeberg, R. McInnes, S. M. Kristiansen, R.J. Petersen, H. Liu, T. Goldhammer, Sulphate in freshwater ecosystems: a review of sources, biogeochemical cycles, ecotoxicological effects and bioremediation, Earth Sci. Rev. 212 (2021) 103446, https://doi.org/10.1016/ j.earscirev.2020.103446.

[39] Q.H. Zhang, W.N. Yang, H.H. Ngo, W.S. Guo, P.K. Jin, M. Dzakpasu, S.J. Yang, Q. Wang, X.C. Wang, D. Ao, Current status of urban wastewater treatment plants in China, Environ. Int. 92-93 (2016) 11-22.

[40] X. Zhang, Z. Hu, H.H. Ngo, J. Zhang, W. Guo, S. Liang, H. Xie, Simultaneous improvement of waste gas purification and nitrogen removal using a novel aerated vertical flow constructed wetland, Water Res. 130 (2018) 79-87.

[41] Y.Q. Zhao, A.O. Babatunde, Y.S. Hu, J.L.G. Kumar, X.H. Zhao, Pilot field-scale demonstration of a novel alum sludge-based constructed wetland system for enhanced wastewater treatment, Process Biochem. 46 (1) (2011) 278-283.

[42] X.u. Zhou, R. Wang, H. Liu, S. Wu, H. Wu, Nitrogen removal responses to biochar addition in intermittent-aerated subsurface flow constructed wetland microcosms: enhancing role and mechanism, Ecol. Eng. 128 (2019) 57-65.

[43] T. Zhu, J. Gao, Z. Huang, N.a. Shang, J. Gao, J. Zhang, M. Cai, Comparison of performance of two large-scale vertical-flow constructed wetlands treating wastewater treatment plant tail-water: contaminants removal and associated microbial community, J. Environ. Manage. 278 (2021) 111564, https://doi.org/ 10.1016/j.jenvman.2020.111564. 